\title{
The Proposed Plea Bargaining in Ethiopia: \\ How it Fares with Fundamental Principles of Criminal law and Procedure
}

\section{Abstract}

Alemu Meheretu *

The FDRE Criminal Justice Policy embodies multiple reforms that are meant to address the various problems in the Ethiopian criminal justice system. The reforms include the introduction of plea bargaining which represents an unprecedented and ambitious development in the realm of the criminal justice system in Ethiopia. This article examines plea bargaining as envisaged in the FDRE Criminal Justice Policy and the Draft Criminal Procedure Code, from a principle based approach and argues that it hardly lives up to many of the fundamental principles of criminal law and procedure recognised under Ethiopian law. The most affected principles/rights include: the principle of presumption of innocence, the principle of equality, the principle of equality of arms, the principle of truth discovery, the privilege against self-incrimination and the right to silence, and the right to appeal.

\section{Key terms}

Plea bargaining, models of plea bargaining, the proposed plea bargaining, efficiency, fairness, accuracy, Ethiopia

DOI http://dx.doi.org/10.4314/mlr.v10i2.5

\section{Introduction}

Plea bargaining not only occupies a central position in many adversarial jurisdictions, ${ }^{1}$ but also transcends diverse jurisdictions including the inquisitorial

\footnotetext{
* Alemu Meheretu Negash (PhD), Assistant Professor of Law, JU. Email: alemeheret@gmail.com.

I am grateful to the anonymous reviewers for their incisive comments. I also thank Gossaye Ayele for commenting on the initial draft of this Article.This Article is partly based on my PhD thesis titled: 'Introducing Plea bargaining in Ethiopia: Concerns and prospects `. PhD thesis, University of Warwick, UK, 2014.

${ }^{1}$ No jurisdiction relies on plea bargaining as the USA does -more than 90 percent of criminal cases are disposed of using plea bargaining. See United States Sentencing Commission, Statistical Information packet, Fiscal Year 2009 at:

$<$ http://www.ussc.gov/JUDPACK/JP2009.htm> (visited on July 14, 2010). While researches indicate that about $50 \%$ of cases have been settled through plea agreements in
} 
structures. Ethiopia is not an exception. Inspired by such developments, it has adopted plea bargaining at policy level. It is also reflected in some proclamations, albeit not detailed. While defining the powers and duties of the Ministry of Justice (currently restructured as the Federal Attorney General), Proclamation No. 691/2010 and Proclamation No. 943/2016 entrust the latter with the power to plea bargain. This power goes to the newly established Federal Attorney General. This together with the policy represents a step towards providing a legal/policy framework for plea bargaining in Ethiopia, pending the issuance of the new criminal procedure code which is expected to address the concept in detail. However, this power of the Federal Attorney General is yet to be enforced. ${ }^{2}$

This is not to suggest that plea bargaining has no room for application in Ethiopia. Some studies reveal that an informal and rudimentary form of plea bargaining exists at the investigative stage, usually the suspect being unrepresented. ${ }^{3}$ Prosecutors justify this practice in terms of efficiency and the difficulty in obtaining evidence in particular that of witnesses (half a loaf is better than none). The practice of plea bargaining has the following general features $^{4}$ : (a) it applies to any crime, (b) the defendant obtains a range of concessions from total immunity to sentence or charge reductions, (c) it does not involve defence attorneys, (d) it is not enforceable, nor does it form part of the record either in the investigation file or in the judgment.

What is more, cooperation agreements ${ }^{5}$ are recognized through the AntiCorruption $^{6}$, Anti-terrorism ${ }^{7}$, and Witness and whistleblowers protection

Germany; around 90\% of cases in magistrates' courts and $67 \%$ in Crown courts get disposed of through guilty pleas without a trial. See Maike Frommann (2009), 'Regulating plea bargaining in Germany: Can the Italian approach serve as a Model to guarantee the independence of German Judges', Hanse Law Review, Vol. 5, p. 200; A. Ashworth and M. Redmayne (2010), The Criminal Process, $4^{\text {th }}$ ed, Oxford University Press, p. 418.

2 Probably, the fact that the law is generic and the absence of procedural law on the subject matter could be partly responsible for this. As a law meant to define the power and duties of the AG/the Ministry, the proclamation simply lists the power and duties of the AG, the power to allow plea bargaining being one of them.

3 See for example Alemu Meheretu (2014), 'Introducing plea bargaining in Ethiopia: concerns and prospects', (PhD thesis, University of Warwick, UK); UNODC (2011), 'Assessment of the Criminal Justice system in Ethiopia; in support of the Government's reform efforts towards an effective and efficient criminal justice system', p. 54.

${ }^{4}$ Alemu M., supra note 3, ch. 5.

${ }^{5}$ Cooperation agreements are agreements whereby a defendant agrees to cooperate in the prosecution of co-offenders by supplying a testimony so that he/she receives lenient treatment or immunity. Some literatures see cooperation agreements as one form of plea bargaining. But this is not sound because cooperation agreements are about finding evidence that will be tested in full scale trials while plea bargaining is about avoiding full scale trials. However, it is important to note that the two may overlap in a sense that a 
Proclamations. ${ }^{8}$ Despite its practical significance in many jurisdictions, plea bargaining has been a subject of controversy since its inception. Detractors blame it for undermining fundamental safeguards, risking wrongful convictions, and eroding the purpose of criminal sanctions. ${ }^{9}$ On the other hand, proponents dismiss such accusations altogether and capitalize on its positives. ${ }^{10}$ Yet, some prefer to remain in the middle i.e., acknowledging the flaws of plea bargaining but at the same time enticed by its practical benefits uphold it and often propose reforms to rectify its flaws. ${ }^{11}$

Generally, proponents of plea bargaining praise it for its role in managing caseload, enhancing the efficiency of the criminal process, and sparing

defendant may plead guilty and at the same time help the prosecution by testifying against his accomplices.

${ }^{6}$ Article 43(1), The Federal Anti-corruption Special Procedure and Rules of Evidence (Amendment) Proclamation No. 239/2001.

7 Article 33, The Anti-terrorism Proclamation No. 652/2009.

${ }^{8}$ Article 3, Protection of Witnesses and Whistleblowers of Criminal Offences

Proclamation No.699/2010.

${ }^{9}$ See for example Guidorizzi, Douglas (1998), 'Should we really ban Plea bargaining?: The core concerns for plea bargaining critics', Emory L. J. Vol. 47, p.753 ; Kipnis, Kenneth (1976) ,'Criminal Justice and the Negotiated Plea', Ethics Vol. 86, p. 93; R.A. Fine (1987), 'Plea bargaining : an unnecessary evil', Marquatte law Review, Vol.70 No.4, p.615 (arguing that plea bargaining encourages crime by weakening the credibility of the system); Sam W.Calan (1979), 'An Experience in Justice without Plea Negotiation', Law \& Society Review Vol. 13 p. 327; Penny Darbyshire (2000), 'The mischief of plea bargaining and sentencing rewards', Criminal Law Review; Douglas Smith(1986) 'The Plea-Bargaining Controversy' Journal of Criminal Law and Criminology, Vol.77, No.3, pp. 949-968.

${ }^{10}$ See for example Joseph A. Colquitt (2000-2001), 'Ad hoc plea bargaining', Tul. L. Rev. Vol.75, p. 695 (who argues that plea bargaining is a necessary and a legitimate way of disposing criminal cases; the only problem lies on the practice where 'many of the plea agreements struck are inappropriate, unethical, even illegal.'); John Bowers(20072008),'Punishing the Innocent', U. Pa. L. Rev. Vol. 156, p.1119 (Where the author argues that the innocence problem springs from misperceptions over: ' (1) the characteristics of typical innocent defendants, (2) the types of cases they generally face, and (3) the level of due process they typically desire'.); Thomas W. Church (1979), 'In defense of pleas bargaining', Law \& Society Review, Vol.13, No.2, Special Issue on Plea Bargaining, pp. 509-525.

${ }^{11}$ For some detailed works in this regard see e.g. F.H. Easterbrook (1992), 'Plea bargaining as compromise, Yale L.J. Vol.101, p. 1969; Oren Bar-Gill \& Oren Gazal Ayal (2006), 'Plea Bargains Only for the Guilty', J.L. \& Econ. Vol.49, p.353 (proposing a screening model to limit plea bargaining to the guilty); Note (1972), 'Restructuring the Plea Bargain', Yale L.J. Vol. 82, p.286 (arguing for judicial participation in plea negotiations); Note (1972), 'Plea Bargaining: the Case for Reform', U. Rici. L. Rev. Vol.6, p. 325 (proposing open, formalized plea bargaining procedures). 
defendants and victims from the trauma of trials, ${ }^{12}$ while opponents challenge the very foundation of plea bargaining as contrary to constitutional principles, ethics, and fair trial guarantees. ${ }^{13}$ This article singles out one dimension of the controversy i.e., the debate on whether it is compatible with fundamental principles of criminal law and procedure and interrogates whether plea bargaining, as adopted by the criminal justice policy ${ }^{14}$ and the draft criminal procedure code ${ }^{15}$, lives up to the fundamental principles of criminal law and procedure recognised in Ethiopia. Whilst some of such principles are closely linked with plea bargaining, others are remotely associated with it. This article takes up only those principles (from the former category) which are designed to ensure the integrity of the criminal process. It is believed that the article can evoke debate and have positive contributions in shaping the proposed law on plea bargaining.

The first two sections of the article highlight the nature and type of plea bargaining and the models of plea bargaining in different structures of criminal justice. These sections explain plea bargaining, and its types and models. The third section briefly deals with policy justifications and the particular model that Ethiopia has aimed at. The last section examines whether this model is in conformity with principles and rights embodied in the Ethiopian legal regime such as the presumption of innocence, the principle of equality and nondiscrimination, the principle of truth finding, the right to silence and the privilege against self-incrimination, the principle of equality of arms and the right to appeal. This involves analysis of policy documents (the Criminal Justice Policy being the main target), the proposed law on criminal procedure, the FDRE Constitution, criminal laws and the relevant literature.

\section{Meaning and Types of Plea bargaining}

\subsection{Meaning}

Definitions of plea bargaining vary considerably from one context to another. Some perceive plea bargaining broadly as any favorable treatment to a

${ }^{12}$ See for example K.V.K. Santhy (2013), 'Plea Bargaining in Indian and US Criminal Law: Confessions for Concessions' NALSAR Law Review,Vol.7,No.1, p.99; On the economic analysis of plea bargaining, see Landes, William M. (1971), 'An economic analysis of the courts', J. L. \& Econ., Vol.14, No.1, pp. 61-107; Kobayashi, Bruce H. and John R. Lott (1996), 'In defense of criminal defense expenditures and plea-bargaining', Int'l Rev. L. \& Econ., Vol.16, pp. 397-416.

13 S. Schulhofer (1991-92), 'Plea bargaining as disaster', Yale L.J. Vol.101, p.1979.

${ }^{14}$ FDRE (2011), The Criminal Justice Policy of Ethiopia, (Here in after the Criminal Justice Policy).

15 The Federal Democratic Republic of Ethiopia Draft Criminal Procedure Code, 2013 as was valid in June 2013. 
defendant in return to not only pleading guilty but also waiving some rights as the right to appeal and the right to a preliminary hearing and testifying against other suspects. ${ }^{16}$ However, this seems to unduly expand plea bargaining and confuse it with the broader spectrum of negotiated justice which involves many concessions. Simply put, all negotiated justice is not plea bargaining, but plea bargaining is one form of negotiated justice.

Plea bargaining has been defined as 'any agreement by the accused to plead guilty in return for a promise of benefit'. ${ }^{17}$ In a similar fashion, plea bargaining is defined as 'the defendant's agreement to plead guilty to a criminal charge with the reasonable expectation of receiving some consideration from the state'. ${ }^{18}$ In both definitions the defendant by pleading guilty (and not standing as a witness for fellow offenders, as some prefer to include) agrees to trade his/her right to full scale trial in exchange for 'some considerations from the state'. Some suggest that the phrase 'with reasonable expectation of receiving benefit' includes what is termed as implicit plea bargaining in a sense that the offer need not necessarily come expressly from the prosecutor. Instead, reasonable expectation of the defendant to be treated leniently by pleading guilty suffices to imply plea bargains. ${ }^{19}$ In various literature, this is sometimes referred to as implicit plea bargaining

However, this conception unnecessarily expands the ambit of plea bargaining to include any guilty plea disposal of cases. This means that one can find plea bargaining in any jurisdiction which does not recognize or practice plea bargaining per se but simply allows guilty plea disposal of criminal cases. Such expansive conception overstretches the notion of plea bargaining off the mark.

${ }^{16}$ See William F. McDonald (1979), 'From Plea negotiation to coercive Justice: Notes on the respecification of a concept', Law \& Society Review, Vol. 13, pp.389-90.Testifying against other suspects, often known as cooperation agreements is different from plea bargaining. While cooperation agreements are about finding evidence and thus do not avoid full-scale trials, plea bargaining is about avoiding or shortening full-scale trials. "when one defendant agrees to testify against another ... his statements will be subject to refutation and critical evaluation in the courtroom", a phenomenon alien in plea bargains. See Alschuler (1979), 'Plea bargaining and its History', Colum L. Rev.Vol.79, p.4. On the contrary, some recognize cooperation agreements as one form of plea bargaining. See William F. McDonald, already cited.

${ }^{17}$ Joseph Di Luca (2005), 'Expedient MC Justice or Principled Dispute Resolutions? A review of plea bargaining in Canada', Crim. L.Q., Vol.50, p.14 [citing Law Reform Commission of Canada (1975), Criminal Procedure: Control of the process, working paper No 15, p. 45].

${ }^{18}$ William F. McDonald (1979), 'From Plea negotiation to coercive Justice: Notes on the Respecification of a Concept', Law \& Society Review, Vol. 13, Special Issue on Plea Bargaining, p.388 [citing Herbert S. Miller et al (1978), Plea bargaining in the United States].

${ }^{19}$ Ibid. 
Another limitation of the above definitions is that they do not specify the considerations defendants get in exchange to pleading guilty. The broad nature of the definitions may create an impression that any form of concession even if unrelated to sentence or charge may be included. Nonetheless, it must be understood that such considerations should manifest themselves only in lower sentences or charges or some favorable facts. ${ }^{20}$ Thus, plea bargaining can be defined as a form of negotiation/settlement between the state and the defendant whereby the latter agrees to plead guilty in return to charge or sentence concessions. $^{21}$ These concessions take the form of less severe charges or dropping of charges/counts (commonly referred to as charge bargaining) or some leniency regarding the punishment (sentence bargaining). It is this definition that will be employed in this article.

\subsection{Types of plea bargaining: charge bargaining and sentence bargaining}

Generally, the type of concessions a defendant gets in exchange for pleading guilty determines the type of plea bargaining. Plea bargaining that involves reduction of either the number of charges (counts) or the severity of charges (offences) is commonly referred to as charge bargaining; whereas, a type of bargaining which involves a recommendation of more lenient sentence is referred to as sentence bargaining.

Charge bargaining represents a kind of negotiation where a defendant agrees to plead guilty to a criminal charge in return for dismissal of one of the counts or the defendant pleading guilty for a lesser charge than he/she could otherwise face at the trial. ${ }^{22}$ The former is known as horizontal plea bargaining and the latter vertical plea bargaining. ${ }^{23}$ Charge bargaining does not directly involve the sentence the defendant receives although the driving force behind it obviously rests on the desire to get the least possible sentence for a reduced charge. Inquisitorial/mixed structures are generally skeptical of the virtues of charge bargaining. For instance, Germany and Italy, by expressly proscribing it, exclusively rely on sentence bargaining; and so does Russia. In contrast,

${ }^{20}$ For some detailed list of concessions that may accrue to a defendant see Cohen and Doob (1989-90), 'Public Attitudes to Plea bargaining', C.L.Q Vol.32,pp. 86-87.

${ }^{21}$ Black's Law (8th ed. 2004), p. 3657, defines the term in a similar fashion as:

A negotiated agreement between a prosecutor and a criminal defendant whereby the defendant pleads guilty to a lesser offense or to one of multiple charges in exchange for some concession by the prosecutor, usu. a more lenient sentence or a dismissal of the other charges.

${ }^{22}$ Ibid

${ }^{23}$ While vertical charge bargaining relates to the severity of the charge (a charge of first degree homicide can be lowered to that of ordinary homicide), horizontal charge bargaining affects the counts (one or more of the several counts may be dropped). 
adversarial structures such as USA consider charge bargaining as part of a prosecutor's charging discretion and thus put very limited restraint on it. In England too, charge bargaining, which often takes place well before the charge is formally filed, is less objectionable than sentence bargaining which in some way involves the judge, and is in effect, believed to interfere with his /her neutrality. ${ }^{24}$

Under sentence bargaining, the prosecutor agrees to propose lenient sentence following the defendant's guilty plea, and the concessions may include shorter prison terms, probation or referring to rehabilitation centers. ${ }^{25}$ Some further expand the scope of sentence bargaining to include a wide range of concessions. ${ }^{26}$ Sentence bargaining appears to involve an abandonment of the judge's sentencing responsibility. ${ }^{27}$ Nevertheless, at least in theory, this is not the case as it is up to the judge to endorse or reject such recommendations. It is interesting to note that sentence bargaining varies across jurisdictions. Unlike adversarial systems, its scope is much more limited in inquisitorial procedures. The limitation manifests itself in the type of the offense it applies to, the type of concessions involved and the amount of sentence that can be reduced by negotiation. ${ }^{28}$

${ }^{24}$ Francoise Tulkens,(2005), 'Negotiated Justice', [in Demas-Marty and J.R. Spencer, Editors(2005), European Criminal Procedures 4th ed, (Cambridge University Press), p. 665].

${ }^{25}$ Larry K. Gaines and Roger Leroy Miller,(2009) Criminal Justice in Action, (Cengage Learning, Inc,), p. 295. For more discussion, see for example Sanders, et al (2007), Criminal Justice, (Oxford: Oxford University Press).

${ }^{26}$ Such concessions include:

"judges agreeing to impose specific time limits on probation...;prosecutors refraining from raising special sentencing provisions for repeat offenders; prosecutors remaining silent at the sentencing hearing ;or not opposing defendants request for leniency or specialized rehabilitation program; prosecutors downplaying the harm to the victims; and agreement that a defendant serves sentence at a particular institution;..., imposition of a fine or restitution; prosecutors agreeing to schedule sentencing before a lenient judge."

See Kress(1980), Prescription for Justice: the theory and the Practice of Sentencing Guidelines, 87 cited in William W. Wilkins(1988), 'Plea negotiation ,Acceptance of responsibility, Role of the offender and departures :Policy decision in the promulgation of Federal Sentencing Guidelines', Wake Forest L. Rev. ,Vol. 23, pp. 185-86.

${ }^{27}$ Ibid.

${ }^{28}$ While sentence bargaining in adversarial procedure in general applies across the board to all crimes and the amount of sentence concession is not limited (at least statutorily), it works otherwise in inquisitorial procedures- the type of offence and the amount of sentence concession are statutorily fixed. See Generally Stephen C. Thaman (2007), 'Plea bargaining, Negotiating Confessions and Consensual Resolution of Criminal cases' Electronic Journal of Comparative Law, Vol. 11. 


\section{Models of Plea Bargaining and Structures of Criminal Procedure}

Plea bargaining has its roots in the adversarial systems. ${ }^{29}$ Some even go further to make it adversarial by nature. ${ }^{30}$ Researches indicate that it is perceived as 'the ultimate expression' of 'adversarialism', giving parties maximum control over the case outcome. ${ }^{31}$ An intriguing question which is often raised is why plea bargaining has long characterized the adversarial structures and not the inquisitorial? Although it is difficult to label plea bargaining as adversarial as some suggest, studies show that it derives its existence from this structure of criminal procedure. ${ }^{32}$ Relatively, this structure is configured and works in such a way to lend itself for negotiation in the context of a criminal process that involves a dispute between autonomous parties. ${ }^{33}$ This together with the fact that resolution of disputes naturally involves negotiation makes adversarial structures suitable for plea bargaining to flourish.

This can be contrasted with the inquisitorial system`s official inquiry of the truth and their conviction that truth cannot be negotiated. ${ }^{34}$ Moreover, the guilty plea procedure, the passivity of the judge and the nearly unfettered charging power of the prosecutor, which are some of the features of adversarial systems but non-existent in inquisitorial systems, afford a fertile ground to negotiate on

${ }^{29}$ See Lawrence M. Friedman (1978-79), 'Plea bargaining in historical perspective', Law \& Soc'y Rev. Vol. 13, p. 247; A. W. Alschuler (1979), 'Plea bargaining and its History', Colum L. Rev. Vol.79,p.1 ; Malcolm M. Feeley (1997), 'Legal Complexity and the Transformation of the Criminal Process: The Origins of Plea Bargaining ', Isr. L. Rev., Vol. 13, pp. 202-05.

${ }^{30}$ Some argue that the fact that plea bargaining places the adversarial trait of leaving the criminal proceeding to the party's control than to the judge, makes it adversarial. On the other hand, others claim to the contrary -they maintain that plea bargaining collapses the power of investigation, charging, sentencing into the hands of one actor, the prosecutorand relies on written evidence (the plea agreement instead of tested oral evidence). In this sense, it resembles inquisitorial structures. On these debates, see generally Gerard E. Lynch (1998), 'Our Administrative System of Criminal Justice', Fordham L. Rev.,Vol. 66, p. 2117 ; Maximo Langer (2005-06), 'Rethinking plea bargaining: the practice and reform of prosecutorial adjudication in the American Criminal Procedure', Am. J. Crim. L. Vol.33, p. 223.

${ }^{31}$ Jacqueline Hodgson and Andrew Roberts (2010), 'An Agenda for Empirical Research in Criminal Justice: Criminal process and prosecution', Legal Studies Research Paper No 2010-13, p. 25. (Showing their reservations on such labeling of plea bargaining).

${ }^{32}$ Supra note 29.

${ }^{33}$ See Mirjan Damaska (1975), 'Structures of Authority and Comparative Criminal Procedure', Yale L.J., Vol. 84, p. 480.

${ }^{34}$ Ibid. 
guilty pleas and thus for plea bargaining to function. ${ }^{35}$ What is more, unlike inquisitorial systems, the principle of discretionary prosecution forms an important source of discretion for prosecutors in the adversarial structures to choose whom to charge, what to charge, how much to reduce, and even to drop charges altogether. All these flexibilities, which are prerequisites for plea bargaining, are present in adversarial structures. ${ }^{36}$

In contrast, the continental rule of compulsory prosecution ${ }^{37}$ seems to contradict the adversarial style of plea bargaining. So long as sufficient evidence exists, prosecutors must proceed to trial and defendants cannot abort the trial by just confessing or pleading guilty. Also, the guilty plea which is the subject of negotiation in plea bargaining is generally unknown in inquisitorial systems. ${ }^{38}$ Confession by the accused may not exempt the prosecution from proving its case, and still the court may find the accused not guilty. It is also suggested that plea bargaining is ill-suited with the inquisitorial version of truth -substantive truth. ${ }^{39}$ All these mixed with the negative stance of inquisitorial jurisdictions to plea bargaining ${ }^{40}$ evoke the query as to how plea bargaining works in these jurisdictions.

35 Ibid. See also Thomas Weigend (2008), 'the decay of the Inquisitorial Ideal: plea bargaining evades German Criminal procedure' [in John Jackson et al editors, (2008), Crime, Procedure and Evidence in a Comparative and international context, (Hart Publishing), p. 63.

${ }^{36}$ Yet it does not mean that plea bargaining is something alien to the inquisitorial systems. Maintaining their inquisitorial nature to some extent, inquisitorial countries have been incorporating some adversarial elements including jury trials and plea bargaining. See generally Stephen C. Thaman, supra note 28; Mirjan Damaska, supra note 33.

37 This is not to suggest that all continental systems adhere to this rule horizontally. Variations exist depending on whether a country follows 'the expediency principle' or 'the legality principle'. See Yue Ma (2002), 'Prosecutorial Discretion and Plea Bargaining in the United States, France, Germany and Italy: A Comparative Perspective' International Criminal Justice Review, Vol. 12, p.30.

38 Stefano Maffei (2004), 'Negotiations on 'evidence' and Negotiations on 'sentence' in Italy: Adversarial Experiments in Italian Criminal Procedure", Journal of International Criminal Justice, Vol. 2, pp. 1050-1069.

39 See Thomas Weigend (2003) 'Is the Criminal Process about Truth? A German Perspective', Harvard Journal of Law \& Public Policy, Vol. 26, p. 171 ('plea bargaining cannot be reconciled with the inquisitorial version of truth-seeking').

${ }^{40}$ For instance in Russia, plea bargaining was met with strong opposition: 'In the Russian criminal justice an agreement (in Russian sdelka) -is an immoral, reprehensible, dishonest phenomenon; it is a bargain demeaning the government (vlast) suggesting its helplessness, its inability to solve crimes ... . Negotiations will demean the investigator, the prosecutor and the judge since they will have to bargain with the criminal...' See S Pomorski (2007) 'Modern Russian Criminal Procedure: The Adversarial Principle and Guilty plea' Criminal Law Forum Vol.17, p.129 [citing I. Petrukhin, 'Agreements Regarding Confession of Guilt Are Alien to Russian Mentality']. Here it is important to 
Nonetheless, with an increasing demand for efficiency, the principle of compulsory prosecution has become liberalized in inquisitorial systems to accommodate some trial alternatives. The practice which once was described as typical of adversarial systems has become increasingly common in inquisitorial systems, although, in a different shape. The inquisitorial variant of plea bargaining exhibits marked differences from its counterpart in the adversarial system. Perhaps the difference starts from naming: most inquisitorial systems that introduced plea bargaining did not prefer to use the term plea bargaining. ${ }^{41}$

The inquisitorial variant of plea bargaining is very limited in scope. ${ }^{42}$ It is applied to a limited range of relatively less serious crimes; it passes through strict court scrutiny; ${ }^{43}$ the amount of sentence discount is usually statutorily fixed; and charge and fact bargains are outlawed. ${ }^{44}$ In so doing, inquisitorial jurisdictions have tried to adopt plea bargaining in a controlled and cautious way so that the propensity of using wide sentencing differentials to induce a plea of guilty becomes minimal. ${ }^{45}$ Conversely, plea bargaining in adversarial structures is generally wider in scope. It applies to all crimes and it involves all forms/types of plea bargaining (charge, sentence, and fact). Moreover, a

note that all the literature in inquisitorial structures is not repugnant to plea bargaining. Some argue that plea bargaining which provides defendants a new role of influencing the outcome of the case to their advantage, is preferable over the traditional inquisitorial systems which are dominated by a judge whose purpose is to get confession. For the presentation of some detailed accounts, see Markus D. Dubber and Mark G. Kelman (2009), American Criminal Law, Cases, Statutes, and Comments, $2^{\text {nd }}$ ed., Foundation Press, p. 99.

${ }^{41}$ For instance, while Italy calls it 'application of sentence at the request of parties'; Russia and Germany use 'agreement with the field charges' and 'negotiated agreement' respectively. More than the naming, however, what is important is the content of plea bargaining.

${ }^{42}$ Civil law traditions such as France, Italy, Germany, Spain, Estonia, Poland, Colombia, and Russia all adopt the limited form of plea bargaining, though the scope of its application varies among them.

${ }^{43}$ In Italy for instance, the judge must supervise the Italian equivalent of plea bargaining patteggiamento or party- agreed sentence and must give reasons for such settlements including the congruity of sentence with the crime. See Jeffrey J. Miller (1990), Plea Bargaining and Its Analogues Under the New Italian Criminal Procedure Code and in the United States: Toward a New Understanding of Comparative Criminal Procedure', N.Y.U. J. INT'L L. \& POL. Vol. 22, p. 215.

${ }^{44}$ The most common discount in such countries is one-third reduction of the normal sentence which would have been imposed after trial. Such is the case for example in France, Italy, Columbia, Spain and Lithuania. See Stephen C. Thaman , supra note 28.

${ }^{45}$ These coupled with the nature of the public prosecutor in inquisitorial systems -the fact that $\mathrm{s} / \mathrm{he}$ is not a party to criminal proceedings and thus would not strive to obtain convictions like its counterpart in adversarial systems, could serve as an important check on the prosecutor's discretion in plea bargaining. 
statutorily fixed sentence discount is unknown in adversarial structures. A typical example is the USA's model which takes an extreme form where prosecutors are often accused of threatening defendants with huge sentence differentials so that they plead guilty. ${ }^{46}$

From the foregoing discussions in general and based on its scope of application and the range of discretion it vests in the prosecution in particular, one can identify two models of plea bargaining: the unrestricted/ unlimited model and the restricted/limited model. The first model refers to the unlimited form of plea bargaining which is common in most adversarial systems. It usually involves broader prosecutorial discretion -unlimited sentencing concessions, all types of plea bargaining- sentence, charge, fact bargains, etc. On the other hand, the restricted model denotes a more restrained form of plea bargaining where the prosecutor's discretion in plea bargains is limited. Under the restricted model, concessions are regulated (usually plea bargaining applies to limited range of relatively less serious crimes with a statutorily fixed discount and rigorous judicial scrutiny), charge and fact bargains are outlawed. This form of plea bargaining is quintessential to inquisitorial/mixed structures. Throughout this article, such distinctions will be used in the course of making reference to the models.

\section{Policy Justifications and the Targeted Model in Ethiopia}

\subsection{Policy justifications of plea bargaining ${ }^{47}$}

The FDRE Criminal Justice Policy embodies reforms aimed at: ${ }^{48}$ (1) introducing plea bargaining and compensation for miscarriage of justice (2) strengthening alternative dispute resolution mechanisms (ADR), legal representation and the capacity of investigative organs, among others. Of these, the introduction of plea bargaining represents an unprecedented development in the Ethiopian criminal justice system. The Policy tries to justify the reasons that motivate Ethiopia to introduce plea bargaining. The policy tries to justify plea bargaining from diverse perspectives. The policy justifications that motivate Ethiopia to introduce plea bargaining include: efficiency for the justice system, remorse and

${ }^{46}$ See for example. Ronald F. Wright (2005), 'Trial Distortion and the End of Innocence in Federal Criminal Justice', U. PA. L. REV. Vol. 154 ,p. 79; Maximo Langer, supra note 30.

${ }^{47}$ Here the purpose is to briefly mention the policy justifications of plea bargaining as stated in the criminal justice policy. For an appraisal of the justifications. See Alemu Meheretu, supra note 3. See also Alemu M., An appraisal of plea bargaining policy and purposes in Ethiopia, forthcoming.

48 The Criminal Justice Policy section 14, supra note 14, p. 30. 
rehabilitation of offenders, and protecting victims and defendants from the trauma of trials.

a) Efficiency:

It is often submitted that plea bargaining offers efficiency advantage to the justice system. With the sophistication of criminal law, trials have become extremely complex and resource intensive. Plea bargaining by cutting short resources, time and energy consumed in the criminal process, expedites justice. The Criminal Justice Policy subscribes to this justification in providing that plea bargaining cuts costs and time spent in full scale trials; it also relies on the caseload management justification -that plea bargaining helps reduce case backlog and workload. ${ }^{49}$

\section{b) Remorse:}

The policy validates plea bargaining from remorse perspective -that by encouraging remorse, plea bargaining facilitates the rehabilitation of offenders. ${ }^{50}$ Here the assumption is that a remorseful defendant will take lessons from his/her past wrong and is less likely to commit another crime, and hence deserves less moral condemnation than defendants who insist on challenging the prosecution`s case.

c) Avoiding the trauma of trials:

The Policy further tries to justify plea bargaining from the perspective of victims and defendants, claiming that it benefits both by shielding them from the trauma of public trials. ${ }^{51}$ It is suggested that in addition to minimizing trial inconvenience, plea bargaining has the benefit of avoiding the stigma and embarrassment of going public in a trial both for the defendant and the victim. While the defendant, by pleading guilty to a lesser crime, avoids the high public sigma associated with serious crimes, victims are spared from facing the offender at the examination stage.

\subsection{The Model targeted by Ethiopia}

Although plea bargaining originated from common law legal systems (like the USA and the UK) that are adversarial systems, it has now been transplanted in varying degrees to other systems of criminal procedure including the classical inquisitorial systems. While most of these jurisdictions have adopted plea bargaining in its limited form, some have preferred to have it in its unlimited form. Ethiopia is not an exception to this. Enticed with such developments, Ethiopia has adopted plea bargaining at a policy level. The Draft Criminal

\footnotetext{
${ }^{49}$ Id., p. 36.

${ }^{50}$ Ibid.

51 Ibid.
} 
Procedure Code which is underway, at a very slow pace, has also incorporated plea bargaining. The reading of the provisions of the Draft Criminal Procedure Code and the Criminal Justice Policy ${ }^{52}$ suggests that the targeted version of plea bargaining has the following general features:

First, it is broader in scope, covering any crime across the board and all the commonly known types of plea bargaining -charge bargaining, sentence bargaining and fact bargaining. ${ }^{53}$ Unlike, most countries (especially those from the inquisitorial structure) that transplant plea bargaining in its restricted model, Ethiopia seems to prefer emulating plea bargaining nearly as applied in adversarial systems.

Second, the power to plea bargain vests in the public prosecutor, excluding the police and the courts. The Draft Code expressly reserves this power to the prosecutor.

Third, the Policy and the Draft Code provide legal conditions for plea bargaining. These include the voluntariness requirement, the duty of disclosure, the requirement of sufficient evidence, and in principle mandatory legal representation. ${ }^{54}$ To the extent they are translated into action, these guarantees can influence plea bargaining positively, although they hardly ensure the fairness and accuracy of the system. ${ }^{55}$ Here it is important to note that the 'Ethiopian variant' though framed along the unlimited model, exhibits some variations on legal conditions. A case in point is the requirement of sufficient evidence. This requirement which apparently has no parallel in those jurisdictions that uphold the unlimited model, requires that plea bargaining can be validly made only after the investigation has produced sufficient evidence of guilt. If the enforceability of this requirement is ensured, ${ }^{56}$ it could enhance but not guarantee the integrity of plea bargaining.

Fourth, as it stands now, the amount of concessions in plea bargains is left for the discretion of the prosecutor. In contrast to most inquisitorial jurisdictions

${ }^{52}$ See for example Article 219, 221 and 230 of the FDRE Draft Code, supra note 15 and section 4.5.4 of the Criminal Justice Policy, supra note 14, p. 36.

${ }^{53}$ The Criminal Justice Policy p. 37; see also Article 230 of the Draft code, supra note 15.

${ }^{54}$ Article 221 of the Draft Code, supra note 15.

${ }^{55}$ See section 4 below.

${ }^{56}$ As it stands now the requirement suffers from serious limitations that can reduce it to a mere formality. It is not clear whether the requirement is subject to ex ante judicial review. The standard used to measure sufficiency and reliability of evidence is not clear, either (it makes little sense if a standard higher than the one used to press for a charge is not used). Most importantly, pre-charge bargaining which is permissible under the Ethiopian variant of plea bargaining can be effectively used to circumvent the requirement of sufficient evidence and negotiate on weak cases. 
which put a fixed discount of one-third, ${ }^{57}$ the Ethiopian variant does not fix the amount of concessions. Yet, the possibility of having fixed discounts is not totally closed because the draft law or subsequent guidelines can still provide for fixed discounts.

From the above, it is plain that Ethiopia has, at least at a policy level, adopted the unrestrained model with minor modifications. This chiefly relates to the preconditions attached to the model under consideration: the requirement of sufficient evidence being the main one. The following section investigates the compatibility of this model with fundamental principles of criminal procedure enshrined in the FDRE Constitution and other Ethiopian laws.

\section{Fundamental Principles of Criminal Law and Procedure at Stake}

This section does not claim to discuss principles of Ethiopian criminal law and procedure in detail. Rather, it tries to briefly sketch those fundamental principles and rights which are likely to be affected by the introduction of plea bargaining and investigate how the proposed 'Ethiopian version' of plea bargaining fares with them.

\subsection{The presumption of innocence}

The presupmtion of innocence forms one of the cardinal constitutional principles in many jurisdictions. The FDRE Constitution unconditionally guarantees the right of an accused person to be presumed innocent until guilt is established by a court of law. ${ }^{58}$ Yet, the Criminal Justice Policy ${ }^{59}$, the Draft Criminal Procedure Code ${ }^{60}$ and some statutory laws such as the Anti-corruption law limit the scope of the right by shifting the burden of proof to the accused. The Policy envisions further limtations of the right by law. Such limitations, in addition to the doubts with regard to their constitutionalty, could pose a serious threat to the right. ${ }^{61}$ This is not to suggest that the presumption should remain

\footnotetext{
${ }^{57}$ This refers to the maximum amount of sentence concession the prosecutor may grant to a defendant in exchange for pleading guilty.

${ }^{58}$ Article 20, The Constitution of the Federal Democratic Republic of Ethiopia, Proclamation No. 1/1995.

${ }^{59}$ The policy allows onus reversal in some serious crimes such as terrorism, corruption, organized crimes and crimes against constitutional order. There is one precondition for this -the prosecutor needs to establish basic facts first. See the Criminal Justice Policy, supra note 14 , section 4.4 at 33 .

${ }^{60}$ Article 5(3), the Draft Criminal Procedure Code, supra note 15.

${ }^{61}$ In particular, the permission of further limitations of the right by law could provide the executive impetus to further erode the right.
} 
absolute. It can be limited in exceptional cases as is the case elsewhere, ${ }^{62}$ provided that such limitations do not violate the Constitution. Apart from questions of constitutionality, the permissibility of further limitations, limitations of the presumption in serious crimes ${ }^{63}$ and its propensity to wider interpretation and abuse evoke concerns.

Proponents argue that plea bargaining is in tandem with the presumption of innocence and serves as an effective tool to single out the guilty from the innocent. ${ }^{64}$ The assumption for this argument is that innocent defendants would choose trial over plea bargaining and only the guilty would be targeted by plea bargaining. Yet, there is no conclusive evidence to support this; quite to the contrary empirical evidence elsewhere suggests that both the innocent and the guilty are indiscriminately targeted, if not the reverse. ${ }^{65}$ With increasing

${ }^{62}$ Generally, for modalities of putting limitations to the presumption/onus reversal in Europe (presumption of intent in some crimes which requires the defendant to rebut this, defences and justifications, reversal of onus in specific minor crimes), see J.R Spencer (2005), 'Evidence' [in Mireillie Delmas-Marthy and J.R Spencer, editors (2005), European Criminal Procedures (Cambridge University Press), pp.597-99].

${ }^{63}$ As shown above, the limitation concerns serious crimes as terrorism, organized crimes, corruption and crimes against constitutional order. This seems worrying in Ethiopia for two reasons. First, unlike most jurisdictions where reversal of onus applies to less serious infractions of law (Example France), it works for serious crimes which carry capital or life punishments. In fact, in Italy there were attempts to introduce by law the reversal of onus in serious crimes (organized crimes and corruption). Nevertheless, it was soon rejected as unconstitutional. See Ibid. Secondly, our weak political culture means the limitations are susceptible to abuse by the executive. Indeed, there are reports of politically motivated prosecutions and convictions involving the above crimes. See for example, Country Report on Human Rights Practice for 2012, United States Department of State available at $\mathrm{http}: / / \mathrm{www}$. state.gov/j/drl/rls/hrrpt/2012/af $/ 204120 . \mathrm{htm}$, visited on $14 / 3 / 13$. The report claims that there are about 400 political prisoners in Ethiopia. Recently following the Supreme Court's upholding of 18 years and life sentences of one journalist and one opposition leader respectively, the US Government openly slammed Ethiopia of its politically motivated prosecutions of government critics; See also Assefa Fiseha (2011) , 'Separation of Powers and Its Implication for the Judiciary in Ethiopia', Journal of Eastern African Studies,Vol.5, No.4, pp.702-715; See Linn A. Hammergren (2012), 'Justice Sector corruption in Ethiopia', [in Janelle Plummer, editors(2012), Diagnosing Corruption in Ethiopia: Perception, realities and the way forward for key sectors, p. 215.] (reporting concerns that: Political authorities or higher-level officers direct police to ignore complaints, undertake investigations, or arrest "suspects" without probable cause.)

${ }^{64}$ See Andrew Hessick and Reshma M. Saujani (2001-2002), 'Plea Bargaining and Convicting the Innocent: the Role of the Prosecutor, the Defence Counsel and the Judge', Byu J. Pub. L., Vol. 16, pp. 232. (Raising the argument and critiquing it).

${ }^{65}$ See John Baldwin \& Michael McConville (1978), 'Plea Bargaining and Plea Negotiation in England', Law \& Soc'y Rev.,Vol.13, pp.296-98 (discussing the innocence problem of plea bargaining in England); Samuel R. Gross et al (2005)., 'Exonerations in the United 
concessions tailored against the chance of acquittal ${ }^{66}$ along with strong risk aversion desire of innocent persons (than the guilty) ${ }^{67}$ and their mistrust of the system $^{68}$, innocents are likely to choose plea bargaining and plead guilty simply because they believe it is rational to do so. Most importantly, the argument seems to ignore the implicit presumption of guilt underlying the plea bargaining system without which the latter does not 'procedurally function' ${ }^{69}$

Some proponents further argue that the onus of reversal involved in plea bargaining can be taken as an exception to the presumption: 'the presumption provides for interferences such as plea bargaining, ${ }^{70}$ However, it is unrealistic to label plea bargaining an exception -a dominant system in many jurisdictions (adversarial structures in particular) which induces every defendant, including the innocent, to plead guilty with attractive concessions on the assumption that they might be guilty. There is no support that plea bargaining forms one of the commonly recognised exceptions to the presumption. ${ }^{71}$ The FDRE Constitution accommodates no exception to the presumption that it guarantees, and, in effect, the possibility of making such caveats seems closed at least for now.

Plea bargaining in general and the proposed 'Ethiopian version' in particular operates in disregard of the principle of presumption of innocence in two

States: 1989 through 2003', J. crim. L. \& Criminology, Vol. 95, p.536 (finding 6 \% ( 20 out of 340) of exonerated defendants pled guilty); Albert W. Alschuler (1981), 'The Changing Plea Bargaining Debate', Cal. L. Rev. Vol. 69, p.714.

${ }^{66}$ Studies in some jurisdictions document such trends and some argue that this is 'welldesigned to produce the conviction of innocents'. See Albert W. Alschuler, supra note 65, pp. 714-15.

${ }^{67}$ Studies show that the innocent is inherently more risk averse than the criminal because the latter willingly assumes risk while breaking the law in the first place. Innocents mistrust the criminal process for charging them for a crime they did not commit. Unlike the guilty, they are not psychologically prepared to face the repercussions of public trials. Prosecutors offer innocents similar concessions as the guilty. However, because of difference in evaluating risk, the innocent attaches higher value for it and may choose the lesser evil -plea bargaining. See Andrew Hessick and Reshma M. Saujani, supra note 59, p.201; See also Michael K. Block \& Vernon E. Gerrety (1995), 'Some Experimental Evidence on Differences Between Student and Prisoner Reactions to Monetary Penalties and Risk', J. Legal Stud., Vol. 24, p.138.

${ }^{68 .}$ Some innocent defendants are so mistrustful of the system that they believe their guilt is a foregone conclusion if they stand trial, and so they readily accept any inducement to plead. These feelings of mistrust are sometimes nourished by defence counsel who begin with a presumption of client guilt, and both begin and end the representation by looking for the best available bargain'. See Andrew D. Leipold (2005), 'How the Pre-trial Process Contributes to Wrongful Convictions', Am. Crim. L. Rev. Vol. 42, p. 1154.

${ }^{69}$ See Elizabeth T. Lear (1993), Is Conviction Irrelevant?, UCLA L. REV. Vol. 40, p.1222.

${ }^{70}$ See Samantha J. Cheesman (2014), A comparative Analysis of Plea Bargaining and the Subsequent Tension with an Effective and Fair Legal Defence, (PhD thesis), p. 231.

${ }^{71}$ For some notes on such exceptions, supra note 63. 
respects. First, the plea bargaining offer from the prosecution presupposes an implicit presumption of guilt; i.e., in making offers to negotiate, the prosecutor assumes that the defendant is guilty. ${ }^{72}$ This is plain in particular in pre-charge bargaining (which is permissible in Ethiopia) at which point the prosecution has no sufficient evidence to press for a charge. This clearly contradicts with the principle. Second, plea bargaining lowers the standard of proof. It relies not on evidence as $\operatorname{such}^{73}$ rather on the admission of guilt which is likely to be tailored based on the strength of evidence -the probability of prevailing at trial and the weight of concessions.

Procedural requirements like presumption of innocence and heightened standard of proof are 'intended to prevent inaccurate convictions even at the expense of inaccurate acquittals' ${ }^{74}$ Plea bargaining defies this by trading-off the reliability of convictions to efficiency and economic gains. It permits the prosecution to evade rigorous standards of due process and proof. ${ }^{75}$ This is alarming in jurisdictions like Ethiopia whose criminal process exhibits serious limitations in upholding due process and ensuring the reliability of convictions.

Apparently, the requirement of sufficient evidence, a legal condition put to the 'Ethiopian version' of plea bargaining, could enhance the standard of proof and thus outcome accuracy. Yet, this appears to be unrealistic. This is a determination made by the prosecutor based on untested evidence with little or no pre-trial safeguards to ensure its reliability -no lawyer present, little prosecutorial supervision, no defined standard to measure sufficiency, ${ }^{76}$ no $e x$ ante judicial review; even ex post review and its effects remains equivocal. ${ }^{77}$

72 See generally Sanders, Andrew et al (2010), Criminal Justice, Oxford University Press, p. 496.

${ }^{73}$ When one counts out the guilty plea as unreliable, at best a lower standard of proof which is required for pressing of criminal charges is used to convict the accused and at worst this requirement could be circumvented. Indeed, this possibility is very high in particular with pre-charge plea bargaining permissible. For more discussion on the standard of proof used in plea bargaining, see Gregory M. Gilchrist, Gregory M. Gilchrist (2011), 'Plea Bargains, Convictions and Legitimacy', Am. Crim. L. Rev. Vol.48, p.153 ('Where trials are avoided, the standard of proof required for a conviction can be reduced to mere probable cause'). On the other hand, some suggest that beyond reasonable doubt or even a higher standard of beyond all doubt can be comfortably met if defendants 'candidly' admit their guilt (plea bargaining). See Richard L. Lippke (2011), The Ethics of Plea Bargaining, Oxford University Press, p. 221. But, this is hardly ensured in plea bargains.

${ }^{74}$ George E. Dix (1977), 'Waiver in Criminal Procedure: A Brief for More Careful Analysis', Tax. L. Rev. Vol.55, p. 240.

${ }^{75}$ Douglas D. Guidorizzi, supra note 9 at 768.

${ }^{76}$ The standard is yet to be determined by the prosecutor general. See The Criminal Justice Policy, supra note 14, section 3.10 at 13 (which demands that the Prosecutor General issues directives that provide standards on this). Yet, such approach has its own limitations: First, given the policy's focus on efficiency, the office of the prosecution is 
Nor is the possibility of using illegally or improperly obtained evidence ruled out. Indeed, the criminal justice policy envisages such possibility as an exception. ${ }^{78}$ Thus, the likelihood of inducing guilty pleas with a prosecution having no prospect of success cannot be dismissed; if not highly probable. In fact, this is not mere speculation at least in trials because empirical evidence shows that prosecutors often institute charges without sufficient evidence and preparation. ${ }^{79}$ Plea bargaining is conducive for this since prosecutors have little incentive to weed out weak cases. ${ }^{80}$

Specifically, pre-charge bargaining which is permissible under the proposed variant of plea bargaining can be effectively used to circumvent the requirement of sufficient evidence and negotiate on weak cases. All these coupled with institutional pressure to raise efficiency and own interest to maximize performance could provide prosecutors with good incentives to circumvent the requirement of sufficient evidence. In the circumstances, the requirement of sufficient evidence is likely to remain a mere formalism.

\subsection{The principle of equality}

Both the FDRE Constitution and the Criminal Code embody the principle of equality and proscribe discrimination among defendants 'on grounds of race, nation, nationality, or other social origin, colour, sex, language, religion, political or other opinion, property, birth or other status ${ }^{81}$ However, by treating

less likely to restrain itself meaningfully using its own guidelines. Second, effective enforcement mechanisms of the rules may presuppose external review. But weak culture of judicial review would mean that the guidelines are rarely challenged before courts of law.

${ }^{77}$ It is not clear whether the court must review prosecution evidence before it approves the plea agreement. In fact, it is required to check the consistency of the agreement with the law and morals (Article 232 of the Draft Code). Agreements contrary to the law, code of ethics, morality, and rights and interests of defendants are inadmissible (see Article 229(3) and (5) of the Draft Code). From this, one may imply that the court is obliged to review the requirement of sufficient evidence -a requirement which is provided for by the law. And if the agreement is found contrary to the law, the court must reject it. But this depends on the court's appreciation.

${ }^{78}$ The Criminal Justice policy, supra note 14 at 17.

79 This practice is ironically labelled as 'charging to fail'. See World Bank (2010), Uses and Users of Justice in Africa: the Case of Ethiopia's Federal Courts. (Washington DC: World Bank, ) <http://documents.worldbank.org/curated/en/2010/07/13145799/uses-usersjustice-africa-case-ethiopias-federal-courts $>(7 / 10 / 14)$,p. xxi.

${ }^{80}$ See Oren Gazal-Ayal (2006), 'Partial Ban on Plea Bargains', Cardozo L. Rev., Vol. 27, p. 2299 (by diminishing the cost to the prosecutor of bringing weak cases, plea bargaining decreases the incentive to properly screen out weak cases through prosecutorial discretion at the outset).

${ }^{81}$ See Article 25, the FDRE Constitution and Article 4 of FDRE Criminal Code, 2004. 
similarly situated defendants differently without any principled justification, plea bargaining collides starkly with the equality principle. This problem takes two forms: differential treatments inherent in plea bargaining and those based on invidious grounds.

\subsubsection{Differential treatments inherent in plea bargaining}

Differential treatments, inherent in plea bargaining, take two dimensions, namely between plea and trial defendants, ${ }^{82}$ and differential treatments among plea defendants. Defendants accused of the same crime may be treated quite differently simply depending on their choice of plea. While those who waive trial for plea negotiation are privileged enough to benefit from the generous concessions of prosecutors and receive lesser punishments, those who insist on exercising their right to trial get harsh penalties thereby creating dual sentencing structures. In literature, this is known as trial penalty ${ }^{83}$-a notion which captures the fact that trial defendants receive severe punishment compared with plea defendants, simply for exercising their right to trial.

Even among those defendants who plea bargain, the result of the negotiation appears to be uneven and may perpetuate inequalities. The outcome of the negotiation depends on several extraneous factors of sentencing calculation as opposed to the degree of guilt -notably, the bargaining power of the defendant, the strength of the prosecution evidence, and other subjective considerations. In both cases, plea bargaining sustains differential treatment among similarly situated defendants, and this violates the equality principle and culminates in discrimination. ${ }^{84}$

It can be argued that so long as both options (the option to bargain and the option to go to trial) are readily available to defendants, one cannot speak of discrimination. Yet, this argument holds little water as the options are not comparable to enable one make a free choice. In light of compelling sentence differentials, possible pressure from the prosecutor and the attorney to plead guilty, disproportionate interests at stake and huge power disparity between the

${ }^{82}$ While the notion plea defendants refers to those defendants who plea bargaining, trial defendants connotes those who exercise their trial rights.

${ }^{83}$ For more on this, see Russell D. Covey (2008), 'Fixed Justice: Reforming Plea Bargaining with Plea-Based Ceilings` Tul. L. Rev. VOL.82,P.1237 ("The ubiquity of plea bargaining creates real concern that innocent defendants are occasionally, or perhaps even routinely, pleading guilty to avoid coercive trial sentences."); Albert W. Alschuler (1983), 'Implementing the Criminal Defendant's Right to Trial: Alternatives to the Plea Bargaining System', U. Chi. L. Rev. Vol. 50. pp. 657-59.

${ }^{84}$ For more, see for example Stephen Bibas (2004), 'Plea bargaining Outside the Shadow of a Trial'.117 Harvard Law Review, Vol.117, p. 2468. 
adversaries ${ }^{85}$ defendants would find it hard to go for the trial. As Gifford rightly observes $^{86}$ : '[t]he reality of sentencing differentials is generally enough to deprive defendants of any real choice in plea bargaining.'

Some proponents of plea bargaining justify the differential treatment by making a distinction between rewarding waiver of a right and penalizing its exercise. ${ }^{87}$ Thus, while defendants who waive their right and plead guilty are rewarded, those who prefer to stand trial fail to receive such rewards. However, it seems off the mark to make a distinction between the two notions: if pleading guilty is rewarded generously, the converse -pleading not guilty- is in effect penalized severely. ${ }^{88}$ Besides, the distinction erroneously assumes that justice can be attained in isolation of the principle of equality, ${ }^{89}$ while equal treatment is apparently an essential facet of procedural justice.

\subsubsection{Differential treatments based on invidious grounds}

Even though the conventional criminal justice system (trial) is not immune from this problem -at least in a different version than plea bargaining-, the concern is quite pronounced in plea bargains. The proposed version of plea bargaining which permits all sorts of non-transparent deals to drop or reduce charges, reduce sentence and manipulate facts, is prone to abuses and discriminations based on such invidious grounds as wealth, ethnicity, sex, religion, and political outlook, among others. This is not mere speculation.

For instance, the informal practice of dropping of charges and conversion of custodial sentence to fine indicate the fact that plea bargaining discriminates against poor defendants. ${ }^{90}$ Though in a slightly different context, the informal 'plea bargaining' made with real estate developers accused of crimes relating to land abuse can illustrate this problem. In this case, while government employees

${ }^{85}$ While the prosecutor risks losing its case, the defendant risks his liberty, if not his life. For debates on this problem, see Blumberg (1967), Criminal Justice (Where it has been argued that plea bargaining generates unequal treatment of defendants and that plea bargaining is unconscionable, Id., at 55); Note (1972), 'Plea Bargaining: the Case for Reform', U. Rici. L. Rev. Vol.6, p. 334.

${ }^{86}$ See Donald G. Gifford (1983), 'Meaningful Reform of Plea Bargaining: The Control of Prosecutorial Discretion', U. ILL. L. REV., p.49.

${ }^{87}$ See for example Richard L. Lippke, supra note 73.

${ }^{88}$ See Albert W. Alschuler, supra note 83 at 657-59 (1983), (arguing that :

If the concepts of reward and penalty are relative -if these concepts derive their meaning only from each other- the assertion that some defendants are rewarded and none penalized is simply schizophrenic. As Judge David L. Bazelon, referring to the implausibility of a system in which there are winners but no losers, once observed, "If we are 'lenient' toward [defendants who plead guilty], we are by precisely the same

${ }^{89}$ Ibid. token 'more severe' toward [those who plead not guilty]."

${ }^{90}$ See Alemu Meheretu, supra note 3. 
who took part in the crime have been formally prosecuted, the affluent real estate developers benefited from the dropping of charges in favour of administrative measure of a payment of money. These differential treatments, though said to be justified in the public's interest, ${ }^{91}$ seem to enable wealth to buy justice.

What is more, it would be troubling if plea bargaining includes negotiation on fines which is increasingly used in Ethiopia thereby enabling the rich to easily avoid imprisonment and 'purchase freedom' while the poor desolately face imprisonment. Even worse, the rich could comfortably use plea agreements to cover up their criminal liability in exchange for a payment made to an innocent person who pleads guilty for their crimes.

\subsection{The search for the truth/accuracy}

Although the weight attached to the search for the truth in relation to other values varies across jurisdictions, ${ }^{92}$ any system of criminal procedure targets truth seeking as its major objective. Ethiopia is not an exception. The search for the truth is one of the fundamental principles of Ethiopian criminal procedure law. It is expressly mentioned in the reform that the criminal process needs to be guided by this principle. The Draft Criminal Procedure Code specifically entrusts the judiciary with the duty to uncover the truth so that the criminal accounts for his wrong and the innocent faces no conviction. To this end, the court is allowed to go beyond the facts and arguments forwarded by the parties and call witnesses. ${ }^{93}$ While guilty pleas may dispose of cases, the court is mandated, at its own motion, to conduct a full-scale trial. ${ }^{94}$ In this sense, what is sought seems to be material truth as opposed to procedural truth. ${ }^{95}$

91 The notion of public interest is a fluid concept. Unless carefully construed based on defined standards, which is not the case in Ethiopia, it is open to abuses and discriminations. Perhaps, in the case at hand, one may invoke public interest. Yet, it does not seem consistent with public interest when one considers the seriousness of the crimes; the real estate business has been accused of an entrenched problem the governments vows to address. The concessions exchanged between the government and the suspects can erode public confidence in the justice system.

92 The difference is visible in adversarial and inquisitorial conceptions of the truth. See generally, Weigend, supra note 39 at 157.

${ }^{93}$ See Art 369 of the Draft Code, supra note 15.

${ }^{94}$ See Art 334 of the Draft Code, supra note 15. This echoes Article 135 of existing criminal procedure code.

${ }^{95}$ While material truth is understood to mean an objective truth, procedural truth represents -truth obtained in a contest that involves opposing views of reality in a procedure which ensures the fairness of the process. See Rachel A, Van Cleave (1997), 'An offer you cannot refuse? Punishment without trial in Italy and the United States: The search for truth and an efficient Criminal Justice System', Emory Int'l L. Rev.Vol.11, p.142; Maximo Langer (2004), 'From Legal Transplants to Legal Translations: the Globalization 
It is interesting to see how the principle of search for the truth fares with the proposed 'Ethiopian version' of plea bargaining which involves exchange of concessions and negotiations on facts. Generally, some try to align plea bargaining with the search for the truth. For instance, one writer argues that plea bargaining can get at the truth: (1) where genuine guilty pleas are tendered; (2) in the inquisitorial versions of plea bargaining. ${ }^{96}$ However, it is difficult, if not impossible, to link plea bargaining with the search for the truth for it inherently subverts the latter. While plea bargaining is about compromise and exchange of concessions, the truth is about fact finding regardless of the interest of the parties to strike a deal.

Plea bargaining in general and the proposed 'Ethiopian version' in particular undermine the truth. Trial and pre-trial procedures in any structure of criminal procedure target truth discovery as one major objective, albeit with variations in the conception of truth and methods of establishing it. In the inquisitorial systems, the procedures from investigation all the way to trial and post trial stages are designed in such a way that material truth can be established. ${ }^{97}$ Unilateral and impartial investigation by the state (through the examination of evidence in support and against the conviction of a defendant), active judge, strict reviews, strong standard of proof, etc are designed to promote the truth finding exercise. Likewise, in adversarial systems, it is believed that the fight between adversaries in a structure that ensures fairness is the best way to unearth the procedural truth. ${ }^{98}$ Cross-examination, strong standard of proof, the privilege against self-incrimination and extended exclusionary rules are all believed to be structured to this end.

By requiring a waiver of pre-trial and trial procedures designed to promote outcome accuracy at both criminal procedure systems (above) and substituting it with the haggling of the parties on the bargaining table, plea bargaining obscures the truth, ${ }^{99}$ and it involves "a compromise between adversaries, reached when the parties each independently calculate the terms of the agreement to be preferable to the uncertainty of trial." Indeed, the primary concern of plea bargaining is not fact finding as such. ${ }^{100}$ It is rather about case resolution through compromise and negotiation of facts at the expense of the truth.

of Plea Bargaining and the Americanization Thesis in Criminal Procedure', Harvard International Law Journal, Vol. 45, p.10.

${ }^{96}$ See R. L. Lippke, supra note 73, p. 233-34.

${ }^{97}$ See Rachel A, Van Cleave, supra note 95.

${ }^{98}$ Ibid.

${ }^{99}$ See DK Brown (2005), 'The Decline of Defense Counsel and the Rise of Accuracy in Criminal Adjudication' California Law Review, Vol. 93, p.1610. See also Gregory M. Gilchrist, supra note 73, p. 171); R. L. Lippke, supra note 73, p. 218.

100 Ibid 
In particular, this is for the most part true of the unlimited form of the proposed plea bargaining in Ethiopia where charge bargaining and fact bargaining are tailored to this end. The downgrading or dropping of charges and negotiation of facts, which are tenets of the unlimited model, are simply inconsistent with the truth-seeking objective of the system. In this sense, plea bargaining fails to not only accurately reflect the actual crime committed but may not also make offenders accountable to their crimes with the deserved punishment. The same holds true for sentence bargaining because the huge and uncertain sentence reductions involved in sentence bargains distort truth about what offenders have done. ${ }^{101}$

What is more, the structural problems surrounding the plea bargaining process include factors such as attorney competence, workloads, resources, sentencing and bail rules, information deficits, and defendants' preference to risk; and all these factors impinge on the outcome of plea bargaining. ${ }^{102}$ Moreover, coercive sentencing differentials are issues of concern. In the circumstances, guilty pleas tendered following a bargain are less likely to be genuine. ${ }^{103}$ This is particularly true of jurisdictions like Ethiopia where the above structural problems are quite pronounced while procedural safeguards remain scant. ${ }^{104}$

The clash between truth and plea bargaining is even more apparent where a criminal procedure, as is the case with Ethiopia, is designed to unveil the material truth. Research indicates that plea bargaining fundamentally subverts this version of the truth, in particular. ${ }^{105}$ As shown above, the Ethiopian criminal procedure arguably targets the material truth, which necessitates the presentation of all necessary evidence at the trial. The court is required to examine the factual basis of every guilty plea, go beyond the facts and arguments forwarded by the parties and consider additional evidence. In the circumstances, it is questionable whether plea agreements, which naturally aim to avoid the complete presentation of evidence at trial and which involve exchange of concessions and compromises on facts, can go with the material truth.

A procedure can achieve the truth when it (a) singles out the offender from the innocent, and (b) punishes the former with a sentence proportionate to the degree of guilt. However, the proposed 'Ethiopian version' of plea bargaining (which adopts the unrestrained variant of plea bargaining) involves negotiation and misrepresentation of facts, massive sentence reductions and dropping of

\footnotetext{
${ }^{101}$ R.L. Lippke, supra note 73, p. 233-34.

${ }^{102}$ Stephanos Bibas (2004), 'Plea bargaining Outside the Shadow of Trial', Harvard Law Review, Vol.117, pp. 2468-69.

${ }^{103}$ For details see the literature on the innocence problem, supra note 9.

${ }^{104}$ Alemu Meheretu, supra note 3, pp. 172-83

${ }^{105}$ See for example, Weigend, supra note 39, p. 171.
} 
charges meant to induce guilty pleas and thus promote efficiency, fails on both fronts. i.e., it is incapable of offering a reliable fact finding mechanism to arrive at the truth. Here a question remains ${ }^{106}$ : Where is justice if truth is sacrificed to efficiency and legal expediency contrary to its core aspects of fairness?

\subsection{The principle of equality of arms}

Equality of arms, a fundamental principle of fair trial, involves giving each party a reasonable opportunity to present and defend its case, in those conditions that will not put any party at a disadvantage against its opponent. ${ }^{107}$ This, among others, could relate to access to evidence and the right to review adversary evidence, opportunity to examine witnesses, time to prepare for defence, legal representation, rights of appeal.

Developed by the European Court of Human rights, the principle has now won international acceptance. ${ }^{108}$ In Ethiopia, its components can be discerned from the relevant laws and the Constitution. The proposed Criminal Procedure Code has expressly embraced the principle of equality of arms in its latest version. ${ }^{109}$ This principle aims at ensuring that both parties enjoy comparable opportunities so that the balance in the criminal process is enhanced. This is all the more important in criminal cases where the balance of power skews towards the prosecution.

The power disparity between the adversaries is quite pronounced in the Ethiopian criminal process. While the prosecution enjoys state resources and powers, the defence has none of these and remains very weak. Structural problems such as absence of defence investigation, inadequate public defender's services and the particular circumstances of defendants (who are mostly poor, uneducated, unrepresented and uninformed) exacerbate the situation. This creates an unbridgeable rift of institutional bargaining power. In the circumstances, plea bargaining, which involves disproportionate interests at stake, ${ }^{110}$ aggravates the power imbalance and puts the defendant at serious disadvantage in relation to the prosecutor.

${ }^{106}$ Ken Strutin (2013), 'Truth, Justice, and the American Style Plea bargain', Albany Law Review,Vol.77, No. 3, p. 834.

${ }^{107}$ Kaufman v. Belgium, App. No. 10938/84, 50 Eur. Comm'n H.R. Dec. \& Rep. 98, 115 (1986) (establishing the principle of equality of arms standard).

108 See for example Human Rights Committee, General Comment No. 32, Article 14: Right to equality before courts and tribunals and to a fair trial, U.N. Doc. CCPR/C/GC/32 (2007); Prosecutor v. Tadic, Case No. IT-94-1-A, Judgment of Appeals Chamber (Int'1 Crim. Trib. for the Former Yugoslavia July 15, 1999).

109 Art.15, the draft code, supra note 15.

${ }^{110}$ While the defendant is under a threat of severe sanctions, the prosecutor runs the risk of losing at trial. The two are not comparable by any stretch of imagination. 
In some cases, plea agreements can be inevitable consequences/ manifestations of the inequality of the parties. This may be the case where precharge plea agreements, which are allowed under the proposed 'Ethiopian version', are struck. In such cases, the defendant unaware of both the nature of the charge prepared and evidence marshalled against him, is simply in a disadvantageous position to make an informed decision. This leaves the defendant vulnerable to the manoeuvres of the prosecution and ultimately militates against fairness and outcome accuracy. The exclusive rights that the prosecution enjoys under the reform (the Policy and the Draft Code) on such matters as the right to appeal, the right to have the plea agreement approved by the court, the right to plea bargain anew or resubmit the agreement in case of rejection by the court, exacerbate the problem.

Apparently, the legal conditions to plea bargaining such as the duty of disclosure and the requirement of legal representation are meant to address the above concerns. But in reality, this seems unrealistic. First, these guarantees fall short of narrowing down the inherent power asymmetry that is created by plea bargaining. The coercive environment under which plea bargaining operates (i.e., high sentencing differentials, incomparable stakes involved -threat of severe punishment vis-à-vis losing at trial, unequal institutional bargaining power of the parties, among others) remains as a concern. This is particularly true of unlimited plea bargaining where the above safeguards are less likely to be effective. ${ }^{111}$

Secondly and most importantly, material and legal conditions specific to Ethiopia would render the guarantees less effective. For example, legal representation is not always mandatory; in less serious crimes bargaining with unrepresented defendants is allowed. Even in those mandatory cases, the quality and availability of legal service is severely constrained. ${ }^{112}$ Legal aid is poorly organized and remains neglected. This means defendants are likely to negotiate without a lawyer or receive ineffective representation. Similarly, the duty of disclosure would be marred by the absence of effective defence investigation (it is unclear whether parallel defence investigation is recognized), and other

${ }^{111}$ See A. Alschuler (1986), 'Personal Failure, Institutional Failure and the Sixth Amendment', N.Y.U. Rev. L. \& Soc. Change, Vol.14, p.149; Stephanos Bibas (2003), 'The Psychology of Hindsight and After-the-Fact Review of Ineffective Assistance of Counsel', UTAH L. Rev., p.1.

112 See for example 'UNODC Assessment of the Criminal Justice system in Ethiopia; in Support of the Government's Reform efforts towards an Effective and Efficient Criminal Justice System' at 69; Access to Legal Aid in Criminal Justice Systems in Africa Survey




Wonber, Alemayehu Haile Memorial Foundation Periodical. 
problems include the timing of disclosure (which is apparently late during plea negotiation), absence of effective enforcement mechanism (no clear sanction on prosecution`s failure to disclose evidence), and the permissibility of pre-charge plea bargaining.

\subsection{The right to silence and the privilege against self-incrimination}

Both the privilege against self-incrimination and the right to silence are envisaged under the FDRE Constitution (Article19 (2) and 20(3)). The privilege as recognized under the Constitution appears to be limited in scope in two ways: First, the Constitution mentions of the accused, leaving unaddressed, for instance, whether the privilege applies to witnesses. However, the 1961 Criminal Procedure Code allows witnesses under police examination to refuse to answer any question where they believe that it may expose them to criminal liability. ${ }^{113}$ Second, the Constitution protects an accused person from any compulsion to testify against himself/herself, hence arguably limiting the scope of the privilege to testimonial communications as against any real or physical evidence. ${ }^{114}$

One dimension of the right to silence and the privilege against selfincrimination protects suspects from being their own accuser and from undue pressures meant to solicit self-incriminating statements. This is linked to the presumption of innocence. This principle requires the prosecution to prove guilt independent of the accused person's active participation so that defendants are

${ }^{113}$ See the 1961 Ethiopian Criminal Procedure Code, Article 30(2).

${ }^{114}$ Generally the privilege is understood in two senses: narrow and broad. In the USA it is understood in a limited sense to apply only to testimonial communications. While in UK (as well as in the eyes of the ECHR) the broader sense applies- it protects persons from producing documents (real or physical evidence) as well as testifying against themselves (testimonial communications). See generally Ian Dennis (2013), the Law of Evidence (London: Sweet and Maxwell).

Arguably Ethiopia seems to emulate the US approach. The Constitution under Article 19(5) provides :

Persons arrested shall not be compelled to make confessions or admissions which could be used in evidence against them. Any evidence obtained under coercion shall not be admissible. (Emphasis added)

To be sure, the expression confession or admission refers to communications as opposed to real evidence. In this sense, the narrower version of the privilege seems to apply. Yet, one could also argue by emphasizing the phrase any evidence in the second limb of the provision that the privilege implies the protection of any evidence obtained under coercion, real evidence included. 
protected from assisting their own prosecution, ${ }^{115}$ and it protects the accused from coercion or compulsion. ${ }^{116}$

The existence of these rights requires the state to prove its case without the help of the defendant so that its superior power and resources remain counterbalanced. Nonetheless, plea bargaining undermines the right of silence and the privilege against self-incrimination. ${ }^{117}$ Threats and rewards aimed at having a defendant waive his/her right to silence are generally prohibited so that the latter is protected from compulsion. Yet, plea bargaining by inducing, if not coercing defendants to plead guilty on the pain of severe punishment at trial, appears to negate the purpose of the right to silence and the privilege against self- incrimination. In particular, it tends to oppose the essence of the privilege protection against compulsion from providing self-incriminating information.

The requirement of voluntariness, a pre-condition to plea bargaining, seems to offset the above concern. However, since the very concept of plea bargaining operates in sentencing differentials which could be threatening, if not coercive, the problem remains. The inherent coercions involved in plea bargains are beyond the reach of judicial scrutiny. ${ }^{118}$ The coercive environment under which plea bargaining functions (i.e., high sentencing differentials, incomparable stakes involved -threat of severe punishment vis-à-vis losing at trial, unequal institutional bargaining power of the parties, among others) remains beyond their reach. This is especially true of their efforts to ascertain the voluntariness of the guilty pleas. Courts normally check if the guilty plea is free of physical coercion leaving the above coercive conditions (which may taint the outcome) unattended.

One may suggest that the defence counsel could play a role to enhance the fairness and integrity of the plea agreement. Nonetheless, that is not promising for three reasons: First, legal representation is not always mandatory -as indicated earlier, bargaining with unrepresented defendants is permissible in less serious crimes where the defendant consents to it. ${ }^{119}$ Second, even in those

115 This accommodates exceptions to the privilege/scope such as blood test, figure prints etc.

${ }^{116}$ S. Greer (1994), 'The Right to Silence, Defence Disclosure, and Confession Evidence' J. Law \& Soc., Vol.21, pp.107-9; Mike Redmayne (2007), 'Rethinking the Privilege against Self-incrimination', Oxford Journal of Legal Studies, Vol. 27,No.2, pp.218-20.

${ }^{117}$ See for eg. Sanders, Andrew et al, supra note 72, p. 496.

118 All the evidence and information remains at the hands of the parties. The judge is presented with the agreement. Although he may inquire information from the parties, the latter may have little/no incentive to provide him. Nor is the judge allowed to hear victims' account. The requirement of sufficient evidence as shown above is not promising either.

${ }^{119}$ See the Draft Code, supra note 15, article 224. Nonetheless, bargaining with unrepresented defendants is unreliable for: (a) it distorts the power imbalance further; (b) it is not properly sanctioned; (c) any guarantee to it is prone to circumventions. 
mandatory cases, the quality ${ }^{120}$ and availability of legal service is constrained by the limited recognition and respect of defence rights. ${ }^{121}$ Above all, effective counsel is likely to be hampered in an unlimited plea bargains. ${ }^{122}$ Thus, it is probable that many defendants go unrepresented or receive ineffective counsel.

\subsection{The right to appeal}

While the prosecutor is allowed to have appeal rights where the plea agreement is rejected, the defence has no appeal right at all. ${ }^{123}$ One rationale for this seems that once the defendant is convicted based on his admission of guilt while concluding the plea agreement, there is nothing that he can challenge at the appeal stage. ${ }^{124}$ A related rationale goes with the main terms/concessions of the plea agreement. In plea bargaining, a defendant enjoys the benefits of the agreement in exchange for waiving his right to challenge the prosecution evidence in the future, including appeal right. Nonetheless, waiver of the trial does not imply waiver of review by appeal. That is why express bans of appeal are often included by law or inserted in the plea agreement itself.

Perhaps another rationale could relate to the outcome of the rejection of the agreement in that where the agreement is rejected, parties are prompted to go to full-scale trials, in which case the defendant stands to enjoy his/her trial rightsincluding the right to appeal. Surely, this rationale would justify the ban only if full-scale trials were automatic to the rejection of the agreement. Nonetheless, that is not the case. The outcome of rejection of the plea agreement could be to prompt the prosecution to rectify the problem that caused the rejection, to plea bargain anew or to proceed to trial. Thus, to the extent that the outcome is other than going to the trial, the justification is less relevant. The need to appeal may arise where the plea agreement is accepted with modifications or erroneously approved by the court. In this case, the rationale is irrelevant. Some also suggest that the ban on appeal can be justified in the interest of finality and thus

${ }^{120}$ There are concerns as to the quality of legal representation defendants receive. See for example Abebe Asamere, supra note 112.

121 The defence has no/little room to effectively participate in the pre-trial process. Interrogations are conducted in the absence of a lawyer, no parallel defence investigation as such exists, and there is limited defence access to resources and unparallel power between the prosecution and defence.

${ }^{122}$ See A. Alschuler (1986), supra note 111, p.149; Stephanos Bibas (2003), supra note 111.

${ }^{123}$ Art 234, the Draft Code, supra note 15.

${ }^{124}$ This rationale is commonly invoked to ban appeal in full-scale trials where a defendant is convicted based on his/her own guilty plea. As plea bargaining is a self-conviction method (i.e., a method which involves conviction based on admission of guilt), this justification is also valid to the ban of appeal in plea bargaining. 
efficiency. ${ }^{125}$ Yet, efficiency cannot be pursued at all costs in disregard of accuracy and fairness. Thus, there should be some room for appeal.

The ban of appeal leaves defendants with no opportunity to have their guilty pleas reviewed against any irregularity or unfairness in the process that are overlooked by lower courts. ${ }^{126}$ Besides, it is inconsistent not only with the defendant's constitutional right of appeal but also with the principle of equality of arms.

In the foregoing discussion, it is shown that plea bargaining exhibits numerous inconsistencies and clashes with many of the fundamental values and principles of criminal procedure. This is primarily detrimental to defendants. Where a defendant is induced to forgo his/her right to trial and submit to plea negotiations, he/she surrenders several fair trial guarantees. As Professor William Stuntz states: ${ }^{127}$ 'in criminal trials the constitution is omnipresent, in guilty pleas [plea bargaining] it is nearly invisible.'

However, due to its managerial and efficiency advantages, plea bargaining permeates many procedural systems pushing full-scale trials to the margin and making traditional values of fair trial give way for the new value of "process economy"128 - i.e., efficiency. As Damaska observes "the full adjudicative process is everywhere in decline", and he notes that "the novel mode is for authorities to offer concessions to defendants in exchange for an act of self condemnation which permits avoidance of the adjudicative process or at least its facilitation" and thus efficiency. ${ }^{129}$

\section{Conclusion}

Plea bargaining not only occupies a central position in many adversarial jurisdictions but also permeates diverse justice structures including the classical inquisitorial systems. Inspired by adversarial jurisdictions, Ethiopia has adopted the unrestricted or unlimited variant of plea bargaining, at least at policy level in addition to which a draft law is underway.

125 Juliet Horne (2013), Plea Bargains, Guilty Pleas and the Consequences for Appeal in England and Wales (Warwick School of Law Research Paper No. 2013/10 (Special Plea Bargaining Edition). Available at SSRN: http://ssrn.com/abstract=2286681 or $<\mathrm{http}: / /$ dx.doi.org/10.2139/ssrn.2286681>

${ }^{126}$ Perhaps the exception would be review by cassation. However, it is plain that review by cassation is very limited to fundamental errors of law and not facts erred by lower courts.

${ }^{127}$ William J. Stuntz (2006), 'The Political Constitution of Criminal Justice', Harv. L. Rev, Vol. 119, p. 791.

${ }^{128}$ See Regina Rauxloh (2010-110), 'Formalisation of Plea Bargaining in Germany- Will the New Legislation Be Able to Square the Circle?', Fordham Int'l L.J. Vol.34, p. 329.

${ }^{129}$ Mirjan Damaska (2004),'Negotiated Justice in International Criminal Courts', International Journal of Criminal Justice, Vol. 2, p 1019. 
Although this variant of plea bargaining helps reduce case backlog to the extent that the problem correlates with full-scale trials, it is bound to pose its own tribulations which are either inherent to the institution, or typical to the version adopted by Ethiopia, or to the Ethiopian context. This author takes up one dimension of such issues: its relationship with fundamental principles of criminal law and procedure and argues that plea bargaining in general and the proposed Ethiopian variant, in particular is not consistent with such principles which are designed to ensure the integrity of the criminal process. The principles and rights that would be adversely affected include the presumption of innocence, the principle of equality, the principle of equality of arms, the privilege against self-incrimination and the right to silence. Nor is it compatible with one of the main purposes of any criminal procedure -uncovering the truth with the ultimate objective of making guilty defendants account for their wrong.

The magnitude of the problem is not similar in all models of plea bargaining. The problem exists in a mitigated form where plea bargaining is applied in the restricted or limited model which is characterized by statutorily fixed discounts, the ban of charge and fact bargains, and rigorous judicial scrutiny. That is why many inquisitorial/mixed jurisdictions such as Italy, Germany and Russia prefer this model over the unrestrained model, albeit with variations among them. However, this should not suggest that the limited model is capable of remedying the inherent flaws of plea bargaining, such as its inconsistency with fundamental principles and rights. Yet, sentencing differentials can be regulated by law under the limited model of plea bargaining thereby narrowing the gap between trial sentences and plea sentences. This model could also considerably mitigate the flaws of plea bargaining with regard to charge and fact bargains (which lack consistency and utterly defy the truth-finding endeavour). Moreover, rigorous review of the plea agreement applies under the limited model, and this enhances prosecutorial accountability. In this sense, should it be inevitable that Ethiopia uphold plea bargaining, this limited model could be a lesser evil. 